С.В. Нечитайло, І.Є. Ряполов, Д.В. Білий, Д.І. Ярчуківський

Харківський начіональний університет Повітряних Сил ім. І. Кожедуба, Харків

\title{
ВПЛИВ НОСОВИХ ОБТІЧНИКІВ ПІРАМІДАЛЬНОЇ ФОРМИ НА ХАРАКТЕРИСТИКИ ВИПРОМІНЮВАННЯ БОРТОВИХ АНТЕННИХ СИСТЕМ
}

Сучасне ракетне озброєння часто оснащуються радіолокаційними головками самонаведення. Носові діелектричні обтічники, щуо закривають антенні системи (АС) радіолокачійних головок самонаведення сучасного ракетного озброєння, суттєво впливають на їх основні радіотехнічні характеристики. Цей вплив виражається у зниженні рівня головного максимуму діаграми спрямованості (ДС) (зниженні коефіцієнту підсилення антени), запливанні нулів ДС, а також у відхиленні ї̈ максимуму. У зв'язку з иим актуальності набуває питання оцінки негативного впливу обтічника з метою його врахування при проектуванні головок самонаведення та розробки бойових алгоритмів наведення керованої ракетної зброї. Одними з найбільш технологічних у виготовленні є обтічники пірамідальної форми, які можуть розглядатися як перспективні для гіперзвукового ракетного озброєння. У статті представлені результати розрахунку характеристик випромінювання апертурних антен, розташованих під носовими діелектричними обтічниками зазначеного типу. Для вирішення вказаної задачі використаний розроблений раніше в Харківському національному університеті Повітряних Сил метод розрахунку поля випромінюючої апертури у присутності довільної системи розсіювачів (зокрема обтічника). Метод може бути використаний для обтічників інших типів та форм. Розглянуто три типи пірамідальних носових обтічників, щзо відрізняються кількістю граней. Базуючись на отриманих результатах розрахунків надані рекомендації щзодо вибору оптимальних товщин стінок обтічників. Оцінені похибки визначення кутових координат ичілей, щзо вносять розглянуті обтічники при різних кутах сканування головок самонаведення.

Ключові слова: апертурна антена, носовий обтічник, характеристики випромінювання, головка самонаведення.

\section{Вступ}

Постановка проблеми. Аналітики і провідні військові фахівці відзначають, що країна, яка здатна розробити та налагодити серійне виробництво швидкісного високоточного ракетного озброєння (у тому числі гіперзвукового), отримує значну військову стратегічну перевагу. До гіперзвукових літальних апаратів (ГЗЛА) відносяться літальні апарати зі швидкістю більше 5M.

Гіперзвукова зброя добре вписується в нову концепцію ведення війни - Conventional Prompt Global Strike (CPGS) [1-4], (“Глобальний блискавичний удар звичайною (неядерною) зброєю”), яка передбачає можливість нанесення удару по будьякій точці планети протягом 1 години. Вона вкрай скорочує час реагування для протиборчих сторін та передбачає розвиток як високоточних, маневрених ГЗЛА, так і засобів їх перехоплення.

Відзначається, що, наприклад, гіперзвукову високоточну зброю за своїм потенціалом можна порівняти тільки 3 тактичними ядерними боєприпасами. Все вище зазначене обумовлює високий інтерес провідних країн світу до цього питання. Розробка i випробування прототипів гіперзвукової високоточної зброї в даний час проводиться такими країнами як США, Росія, Китай, Франція, Німеччина, Австралія, Японія, Індія, Бразилія та ін. [1].

Враховуючи необхідність точного наведення, передбачається оснащення нових зразків високоточної зброї головками самонаведення (ГСН), які працюють у тому числі й у радіолокаційному діапазоні довжин хвиль. Вони розташовуються під радіопрозорими обтічниками. Одним з ключових питань при розробці радіолокаційних ГСН є оцінювання впливу обтічника на характеристики випромінювання бортових АС ГСН. Виходячи з особливостей динаміки польоту швидкісних високоточних ракет, зарубіжні та вітчизняні фахівці розглядають як найбільш придатною для таких обтічників сильно витягнуту гостру форму (пірамідальну або конусоподібну) із подовженням (відношенням висоти обтічника до діаметру його основи) більшим за 2. Обтічники пірамідальної форми приваблюють своєю технологічністю виготовлення, тому саме на дослідженні їх радіотехнічних характеристик сфокусовано увагу у статті. Хоча використані в роботі методи можуть успішно застосовуватися і для обтічників інших форм.

Аналіз останніх досліджень і публікацій. Для розрахунку випромінювання системи “антенаобтічник” на практиці зазвичай використовуються геометрооптичні методи розрахунку [5-6]. У більшості своїй ці методи не враховують перевідбиття між антеною та обтічником. Деякі обчислювальні методи для розрахунку обтічників літальних апаратів описані у останніх роботах [7-13]. Але, наприклад, у [7] не враховуються перевідбиття, які вини- 
кають під обтічником та можуть суттєво впливати на кінцевий результат. Роботи [9; 11] присвячені тільки оцінці радіолокаційної помітності антенної системи з обтічником та не розглядають характеристики випромінювання антенної системи 3 обтічником. В [13] розглядаються обтічники, що мають малу кривизну у осьовому напрямку, що не виконується у випадку обтічників для швидкісних літальних апаратів. Крім того, у всіх зазначених роботах розглядаються обтічники, що мають форму тіл обертання. Відомі нам публікації не містять результатів, що відносяться до обтічників пірамідальної форми. У роботі [14] представлений розроблений співробітниками Харківського національного університету Повітряних Сил імені Івана Кожедуба метод розрахунку характеристик випромінювання апертурної антени 3 носовим діелектричним обтічником, що враховує перевідбиття від внутрішньої поверхні обтічника та може бути використаний для розрахунку пірамідальних обтічників.

Мета статті полягає в оцінці впливу носових обтічників пірамідальної форми на діаграму спрямованості бортової апертурної антени, яка розташована під ними.

\section{Виклад основного матеріалу}

Розглядається антенна система 3 носовим діелектричним обтічником, який має пірамідальну форму (рис. 1) і виготовлений з кварцової кераміки (ніасіт) 3 відносною діелектричною проникністю $4,2+\mathrm{j} 0,0084$. Бортова антенна система $є$ фазованою антенною решіткою восьмикутної форми (рис. 1).

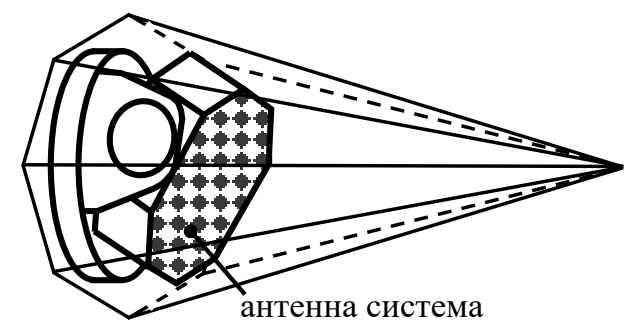

Рис. 1. Зовнішній вигляд антени під носовим діелектричним обтічником

Будемо розглядати три варіанти пірамідальної форми обтічника, а саме обтічник із 6,8 та 10-ма гранями (рис. 2).

При розрахунках модель обтічника будувалась наступним чином. В основі піраміди лежав правильний $N$-кутник $(N=6,8,10)$. Початок системи координат співпадав із центром багатокутника. Радіусвектор вершини обтічника $\vec{r}_{0}=(0,0, h)$. Радіусвектори вершин $N$-кутника $\vec{r}_{i}=\left(x_{i}, y_{i}, z_{i}\right)$, $(i=1, \ldots, N)$. Тут $x_{i}=\rho_{0} \cos \phi_{i} ; y_{i}=\rho_{0} \sin \phi_{i} ; z_{i}=0$, $\phi_{i}=\alpha+\frac{2 \pi}{N}(i-1), \phi_{N+1} \equiv \phi_{1} ; \rho_{0}-$ радіус описаної навколо $N$-кутника окружності.

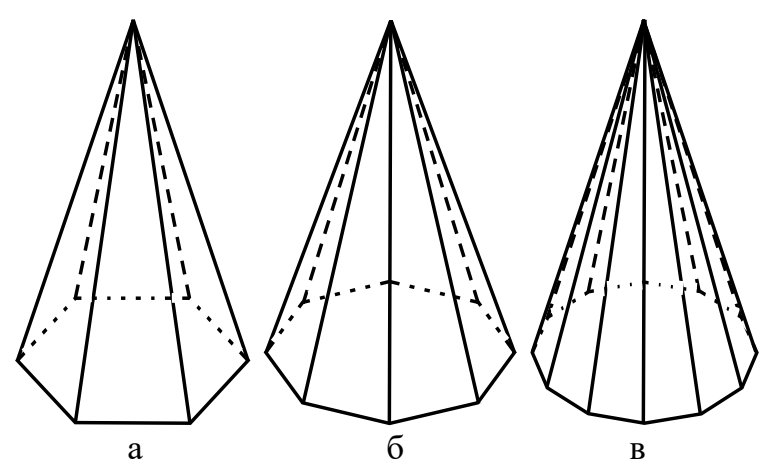

Рис. 2. Форма обтічників, що досліджуються

\section{Метод розрахунку випромінювання апертурної антени 3 обтічником}

Представимо антенну систему у вигляді восьмикутної апертури $S_{0}$ (рис. 3 ), яка вирізана у ідеально провідній площині.

Як було показано у [15], випромінювання такої антенної системи у напрямку орта $\vec{R}^{0}$ може бути представлено формулою:

$$
\begin{gathered}
\vec{p} \cdot \vec{E}\left(\vec{R}^{0}\right)=\int_{S_{0}}\left(\vec{E}^{T}(x) \times \vec{H}_{0}\left(x, \vec{R}^{0}, \vec{p}\right)\right) \cdot d \vec{S}- \\
-\int_{S_{0}}\left(\vec{H}^{T}(x) \times \vec{E}_{0}\left(x, \vec{R}^{0}, \vec{p}\right)\right) \cdot d \vec{S},
\end{gathered}
$$

де $\vec{E}_{0}\left(x, \vec{R}^{0}, \vec{p}\right), \vec{H}_{0}\left(x, \vec{R}^{0}, \vec{p}\right)$ - це поле, що розсіяне “симетризованим” обтічником (рис. 3), у точках $x$ апертури $S_{0}$ (у відсутності ідеально поглинаючого екрана з вирізаною апертурою.
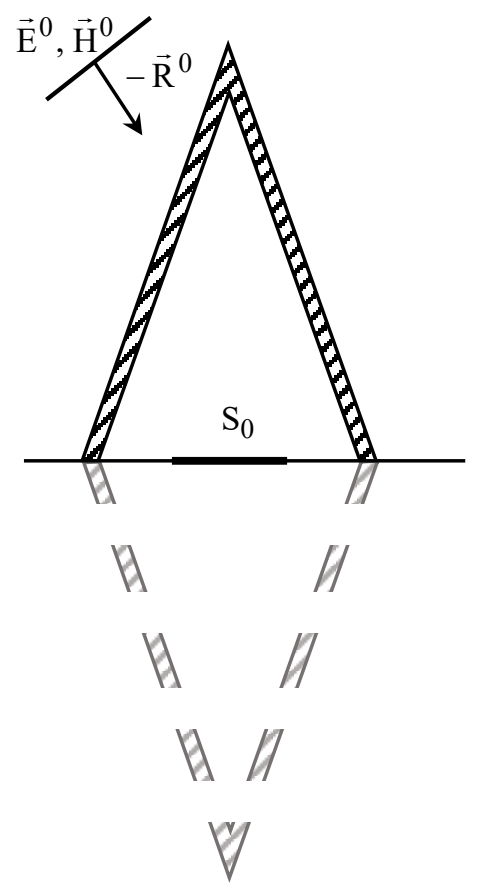

Рис. 3. “Симетризований” обтічник 
Поле $\vec{E}_{0}\left(x, \vec{R}^{0}, \vec{p}\right), \vec{H}_{0}\left(x, \vec{R}^{0}, \vec{p}\right)$, яке породжене падаючою у напрямку $\left(-\vec{R}^{0}\right)$ плоскою хвилею

$$
\begin{aligned}
\vec{E}^{0} & =\left(\vec{R}^{0} \times\left(\vec{p} \times \vec{R}^{0}\right)\right) \exp \left(-j k_{0}\left(\vec{R}^{0} \cdot \vec{x}\right)\right) ; \\
\vec{H}^{0} & =\left(\vec{p} \times \vec{R}^{0}\right) \sqrt{\varepsilon_{0} / \mu_{0}} \exp \left(-j k_{0}\left(\vec{R}^{0} \cdot \vec{x}\right)\right) .
\end{aligned}
$$

Функції $\vec{E}^{T}, \vec{H}^{T}$ - апертурні розподіли тангенціальних компонент векторів поля у наближенні Кірхгофа.

Враховуючи пірамідальну форму обтічника, можна зробити висновок, що рівень поля розсіяння “дзеркального відображення” обтічника у точках апертури буде значно нижче рівня поля, яке пройшло безпосередньо скрізь реальний обтічник. Тому у першому наближенні можна вважати, що $\vec{E}_{0}\left(x, \vec{R}^{0}, \vec{p}\right), \vec{H}_{0}\left(x, \vec{R}^{0}, \vec{p}\right)$ - поле в точках $x$ апертури, що утворене двома шляхами розповсюдження (рис. 4) [14; 16]: прямим проходженням (шлях 1) i перевідбиттів від внутрішньої поверхні обтічника (шлях 2). Інтеграли у (1) обчислювалися методом середніх прямокутників.

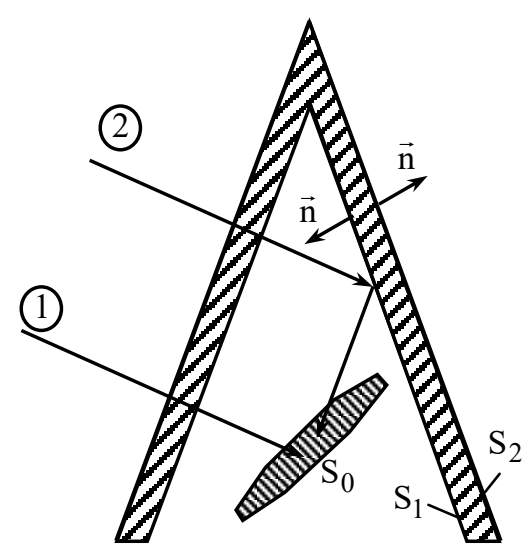

Рис. 4. Шляхи розповсюдження падаючої хвилі

Це поле розраховувалося у наближенні геометричної оптики. Так, поле $\vec{E}_{0}^{1}\left(x, \vec{R}^{0}, \vec{p}\right)$, $\vec{H}_{0}^{1}\left(x, \vec{R}^{0}, \vec{p}\right)$, що відповідає шляху 1 на рис. 4, представляється у вигляді:

$$
\begin{aligned}
& \vec{E}_{0}^{1}(\vec{x})=\left[\tau_{\perp} p_{\perp} \vec{e}_{\perp}+\tau_{\|} p_{\|} \vec{e}_{\| l}\right] \exp \left(-j k_{0}\left(\vec{R}^{0} \cdot \vec{x}\right)\right) ; \quad \text { (2) } \\
& \vec{H}_{0}^{1}(\vec{x})=\sqrt{\frac{\varepsilon_{0}}{\mu_{0}}}\left[\tau_{\perp} p_{\perp} \vec{e}_{\|}-\tau_{\|} p_{\|} \vec{e}_{\perp}\right] \exp \left(-j k_{0}\left(\vec{R}^{0} \cdot \vec{x}\right)\right), \quad \text { (3) } \\
& \text { де } \quad \vec{e}_{\perp}=\frac{\vec{n} \times \vec{R}^{0}}{\left|\vec{n} \times \vec{R}^{0}\right|} ; \quad \vec{e}_{\|}=\left(\vec{e}_{\perp} \times \vec{R}^{0}\right) ; \quad p_{\perp}=\left(\vec{p} \cdot \vec{e}_{\perp}\right) ; \\
& p_{\|}=\left(\vec{p} \cdot \vec{e}_{\|}\right) ;
\end{aligned}
$$

$\vec{n}$ - вектор зовнішньої нормалі у точці поверхні обтічника.

Комплексні величини $\tau_{\perp}, \tau_{\|} \epsilon$ коефіцієнтами проходження плоскої електромагнітної хвилі через плоско-паралельний шар 3 параметрами обтічника на двох взаємно ортогональних поляризаціях [17-18]. Позначкою II помічена (паралельна) поляризація, коли вектор електричної напруженості падаючої хвилі належить площині, що проходить через вектор $\vec{R}^{0}$ і нормаль $\vec{n}$ у даній точці поверхні обтічника. Відповідно, $\perp$ (перпендикулярна) поляризація відповідає ситуації, коли вектор електричної напруженості падаючої хвилі перпендикулярний зазначеній площині. Загальний вираз для коефіцієнта проходження можна представити у вигляді

$$
\begin{gathered}
\tau=\left(\left(\cos \kappa \delta+\frac{j}{c} \sin \kappa \delta\right)+\left(\cos \kappa \delta-\frac{j}{c} \sin \kappa \delta\right) \rho\right) \times \\
\times \exp \left(-j k_{0} \delta \cos \theta\right),
\end{gathered}
$$

де $\rho$ - комплексний коефіцієнт відбиття від плоскопаралельного шару 3 параметрами обтічника, що може бути представлений у наступному вигляді [14-15]:

$$
\rho=\frac{j\left(c^{2}-1\right) \sin \kappa \delta}{2 c^{2} \cos \kappa \delta-j\left(c^{2}+1\right) \sin \kappa \delta} .
$$

$$
\text { У виразі (5) } c=\frac{\sqrt{\varepsilon^{\prime}-\sin ^{2} \theta}}{\beta \cos \theta}, \kappa=k_{0} \sqrt{\varepsilon^{\prime}-\sin ^{2} \theta} \text {, }
$$

$\cos \theta=\left|\left(\vec{R}^{0} \cdot \vec{n}\right)\right|, \sin ^{2} \theta=1-\left(\vec{R}^{0} \cdot \vec{n}\right)^{2}, \varepsilon^{\prime}-$ відносна діелектрична проникність матеріалу обтічника, $\delta$ - товщина обтічника.

$$
\beta=\left\{\begin{array}{l}
1 \text { для } \perp \text { поляризації, } \\
\varepsilon^{\prime} \text { для II поляризації. }
\end{array}\right.
$$

У випадку $\perp$ поляризації $\rho=\rho_{\perp}, \tau=\tau_{\perp}$, а у випадку $\|$ поляризації $\rho=\rho_{\|}, \tau=\tau_{\|}$.

Якщо промінь, що перетинає обтічник у деякій точці $\vec{x}_{0}$, не потрапляє на апертуру $S_{0}$, то він перетинає обтічник ще раз у точці $\vec{x}_{1}$ на “тіньовій” частині поверхні обтічника $S_{1}$. У цьому випадку, обчисливши величини $\tau_{\perp}, \tau_{\|}, \rho_{\perp}, \rho_{\|}, \vec{e}_{\perp}, \vec{e}_{\|}$у точці $\vec{x}_{0}$ за допомогою виразу (2) можна знайти вектор напруженості електричного поля $\vec{E}_{0}^{1}\left(\vec{x}_{1}\right)$, що пройшов крізь обтічник у точці $\vec{x}_{0}$ i потрапляє на внутрішню поверхню обтічника у точці $\vec{x}_{1}$.

Далі вектор $\vec{p}_{1}=\tau_{\perp} p_{\perp} \vec{e}_{\perp}+\tau_{\|} p_{\|} \vec{e}_{\|}, \quad$ напрямок опромінення $-\vec{R}_{0}$ і зовнішня нормаль $\vec{n}\left(\vec{x}_{1}\right)$ до вну- 
трішньої поверхні обтічника $S_{1}$ в точці $\vec{x}_{1}$ використовуються для визначення $\tau_{1 \perp}, \tau_{1 \|}, \rho_{1 \perp}, \rho_{1 \|}, \vec{e}_{1 \perp}$, $\vec{e}_{1 \|}$ за допомогою формул (4), (5). Вираз для поля, відбитого у точці $\vec{x}_{1}$ від внутрішньої поверхні обтічника і падаючого на апертуру антени (шлях 2 на рис. 4) представляється у наступному вигляді:

$$
\begin{aligned}
\vec{E}_{0}^{2}(\vec{x}) & =\left[\rho_{1 \perp} p_{1 \perp} \vec{e}_{1 \perp}+\rho_{1 \Perp} p_{1 \|}\left(\vec{R}^{1} \times \vec{e}_{1 \perp}\right)\right] \times \\
& \times \exp \left(j k_{0}\left[\left(\vec{R}^{1} \cdot \vec{x}\right)-\left(\vec{R}^{0} \cdot \vec{x}_{1}\right)\right]\right) ; \\
\vec{H}_{0}^{2}(\vec{x})= & \sqrt{\frac{\varepsilon_{0}}{\mu_{0}}}\left[-\rho_{1 \|} p_{1 \|} \vec{e}_{1 \perp}+\rho_{1 \perp} p_{1 \perp}\left(\vec{R}^{1} \times \vec{e}_{1 \perp}\right)\right] \times \\
& \times \exp \left(j k_{0}\left[\left(\vec{R}^{1} \cdot \vec{x}\right)-\left(\vec{R}^{0} \cdot \vec{x}_{1}\right)\right]\right),
\end{aligned}
$$

де $\vec{R}^{1}=2 \vec{n}\left(\vec{x}_{1}\right)\left(\vec{R}^{0} \cdot \vec{n}\left(\vec{x}_{1}\right)\right)-\vec{R}^{0}$.

Зауважимо також, що у разі повороту антени на деякий кут площина ідеально поглинаючого екрану 3 вирізаною апертурою також повертається на цей кут. У разі невеликих кутів повороту антени $\left(\leq 25^{\circ}\right)$ всі зроблені припущення про структуру поля $\vec{E}_{0}\left(x, \vec{R}^{0}, \vec{p}\right), \vec{H}_{0}\left(x, \vec{R}^{0}, \vec{p}\right)$ залишаються в силі.

\section{Результати математичного моделювання характеристик випромінювання бортової антенної системи, розташованої під носовим діелектричним обтічником}

За викладеною вище методикою був проведений ряд розрахунків для восьмикутної апертурної антени (максимальний поздовжній розмір - 188 мм, поперечний - 152 мм) (рис. 5, а).

Поляризація антени (напрямок вектору $\vec{E}^{T}(x)$ ) був обраний здовж осі $O^{\prime} x^{\prime}$ (рис. 5, а). Обчислення проводились для перерізу ДС у площині $O^{\prime} x^{\prime} z^{\prime}$ (рис. 5, б) (орт $\vec{p}$ лежить у цій же площині та ортогональний напрямку $\vec{R}^{0}$ ). Для розрахунків вважалося, що апертура антени синфазна та має рівномірний амплітудний розподіл.

Розміри обтічника, котрий використовувався для розрахунків, обирались наступним чином: загальна висота обтічника $h=0,454 \mathrm{м}$; радіус описаної окружності у основі обтічника - 0,12 м. Антенна система розташована відносно обтічника таким чином, щоб площина $O^{\prime} x^{\prime} z^{\prime}$ (площина, в якій розраховувалась ДС антени) була перпендикулярна одній 3 граней обтічника.

Розрахунки проводилися для робочої частоти антени 3,.6ГГц та кутів повороту антени $\alpha=5^{\circ}, 15^{\circ}, 25^{\circ}$. Для кожного варіанту повороту антени та форми обтічника були розраховані залежності величини максимуму нормованої ДС $P$ по потужності (ДС антени нормована до відповідного максимуму ДС при відсутності обтічника) від товщини стінки обтічника.

Як приклад, на рис. 6 та рис. 7 наведені вказані залежності для випадків кута повороту антени $5^{\circ}$ та $25^{\circ}$. Вони мають чітко виражену пікову структуру.
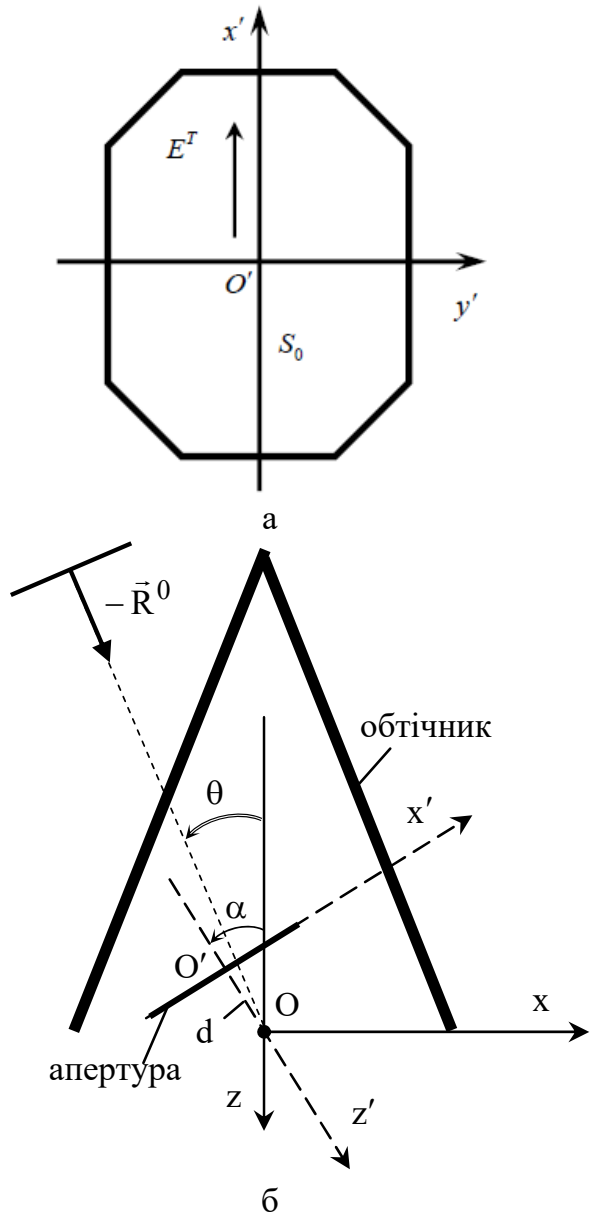

Рис. 5. Геометрія:

а - восьмикутної апертури;

б - розташування апертури під обтічником

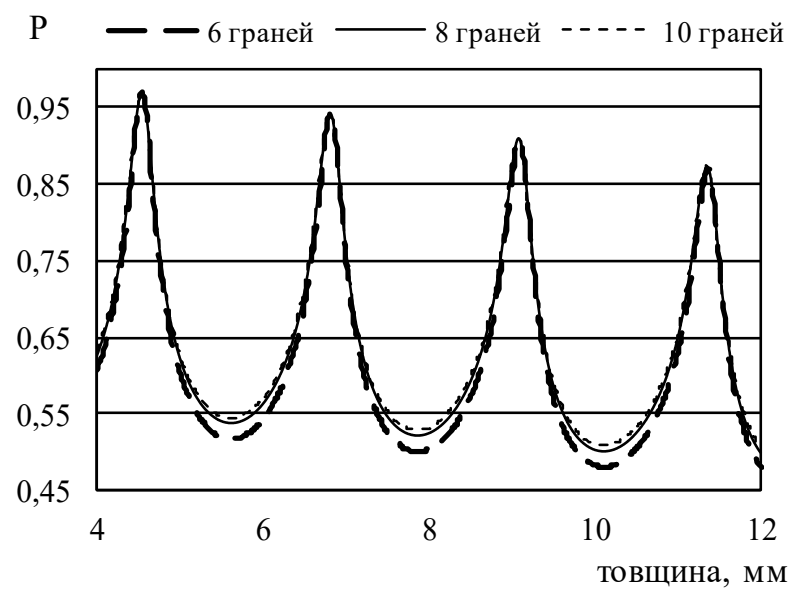

Рис. 6. Нормовані максимуми ДС при куті повороту антени $5^{\circ}$

Максимальні коефіцієнти проходження поля крізь обтічник спостерігаються поблизу значень, кратних половині довжини хвилі у діелектрику. 


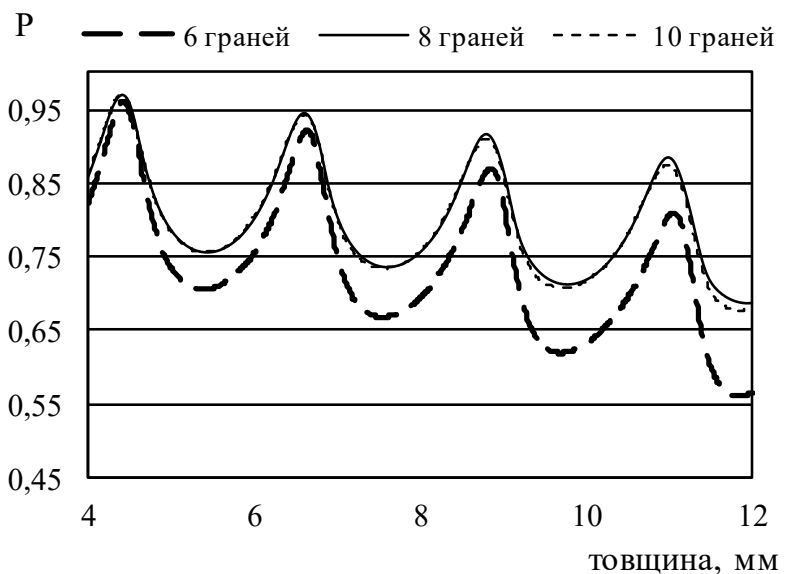

Рис. 7. Нормовані максимуми ДН при куті повороту антени $25^{\circ}$

Далі по розрахованим залежностям отримані оптимальні (по коефіцієнту проходження) товщини стінок обтічників всіх трьох типів. Результати розрахунків оптимальних товщин наведені у табл. 1 .

Таблиця 1

Оптимальні товщини стінок обтічників при різних кутах повороту антенної системи

\begin{tabular}{|c|c|c|c|c|c|}
\hline \multirow{2}{*}{$\begin{array}{c}\text { Кут } \\
\text { пово- } \\
\text { роту } \\
\text { антени } \\
\alpha, \\
\text { град }\end{array}$} & \multirow{2}{*}{$\begin{array}{c}\text { Тип } \\
\text { обтічника } \\
\text { (кількість } \\
\text { граней) }\end{array}$} & \multicolumn{4}{|c|}{$\begin{array}{c}\text { Оптимальна товщина стінки } \\
\text { обтічника, мм }\end{array}$} \\
\hline & & 1 & 2 & 3 & 4 \\
\hline \multirow{3}{*}{5} & 6 & 4.55 & 6.82 & 9.09 & 11.36 \\
\hline & 8 & 4.54 & 6.81 & 9.08 & 11.35 \\
\hline & 10 & 4.54 & 6.81 & 9.08 & 11.35 \\
\hline \multirow{3}{*}{15} & 6 & 4.51 & 6.74 & 8.97 & 11.21 \\
\hline & 8 & 4.49 & 6.74 & 8.97 & 11.2 \\
\hline & 10 & 4.49 & 6.73 & 8.96 & 11.19 \\
\hline \multirow{3}{*}{25} & 6 & 4.43 & 6.64 & 8.849 & 11.05 \\
\hline & 8 & 4.415 & 6.61 & 8.799 & 10.99 \\
\hline & 10 & 4.41 & 6.61 & 8.799 & 10.98 \\
\hline
\end{tabular}

Слід зазначити, що положення максимумів все таки зміщуються в залежності від кута повороту антени і типу обтічника, тому після вибору типу обтічника, який планується використовувати в голівці самонаведення, необхідно провести додаткові дослідження з метою уточнення оптимальної товщини використовуваного обтічника.

Аналіз результатів, наведених на рис. 6, рис. 7 та табл. 1, показує, що при оптимальних товщинах та малих кутах $\alpha$ величини максимумів ДС для всіх розглянутих типів обтічників практично співпадають, тобто кількість гранів обтічника практично не впливає на коефіцієнт підсилення антени (КПА). Однак із збільшенням куту повороту антени $\alpha$ КПА для шестигранного обтічника суттєво знижується відносно аналогічних значень для восьмигранного та десятигранного обтічника. I ця різниця тим більша, чим більша товщина стінок обтічника.

Так для $\alpha=5^{\circ}$ та оптимальних товщин обтічників в районі 11 мм КПА знижується на 13\% у порівнянні з випадком відсутності обтічника.

Для $\alpha=25^{\circ}$ КПА знижується на 12,5\% для десятигранного обтічника, на $12 \%$ - для восьмигранного обтічника та на 19\% - для шестигранного обтічника. Це потрібно враховувати у випадку, коли стане необхідним збільшити товщину стінки обтічника з міркувань підвищення міцності обтічника.

Наступні розрахунки ДС проводились для вказаних у табл. 1 оптимальних товщин стінок обтічників. Нижче на рис. 8-11 наведені нормовані ДС антени $P(\theta)$ по потужності для трьох типів обтічників та кутів повороту $\alpha=5^{\circ}, 25^{\circ}$.

Результати наведені для чотирьох “оптимальних” товщин стінок обтічника.

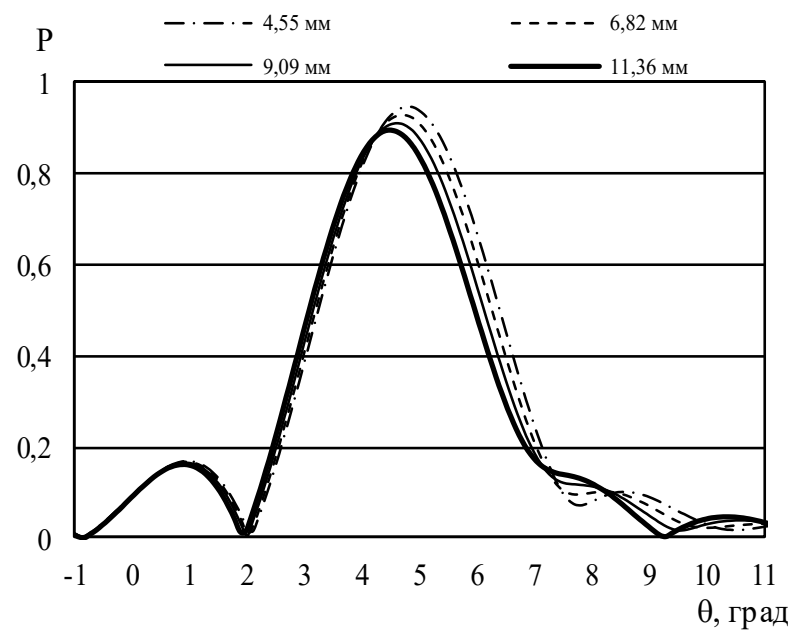

Рис. 8. Нормовані ДН АС під шестигранним обтічником при куті повороту антени $\alpha=5^{\circ}$ для різних “оптимальних” товщин стінки обтічника

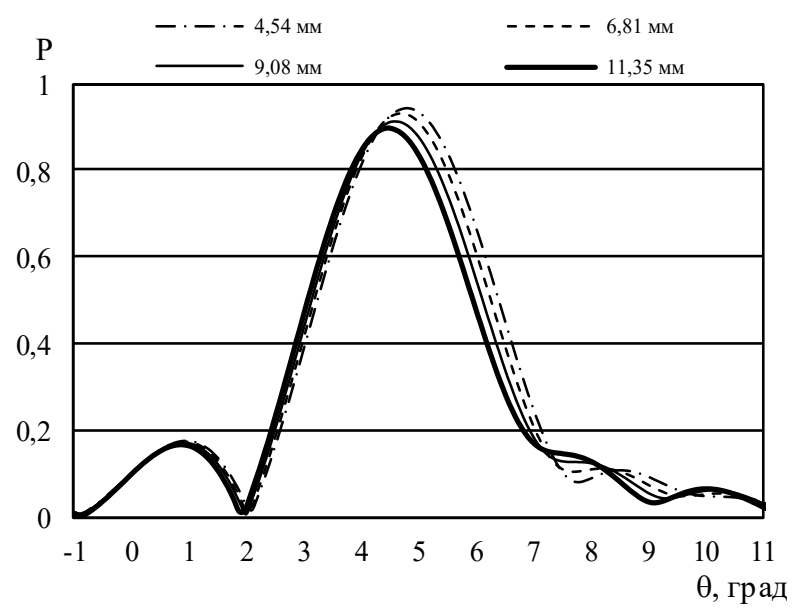

Рис. 9. Нормовані ДН АС під десятигранним обтічником при куті повороту антени $\alpha=5^{\circ}$ для різних “оптимальних” товщин стінки обтічника 


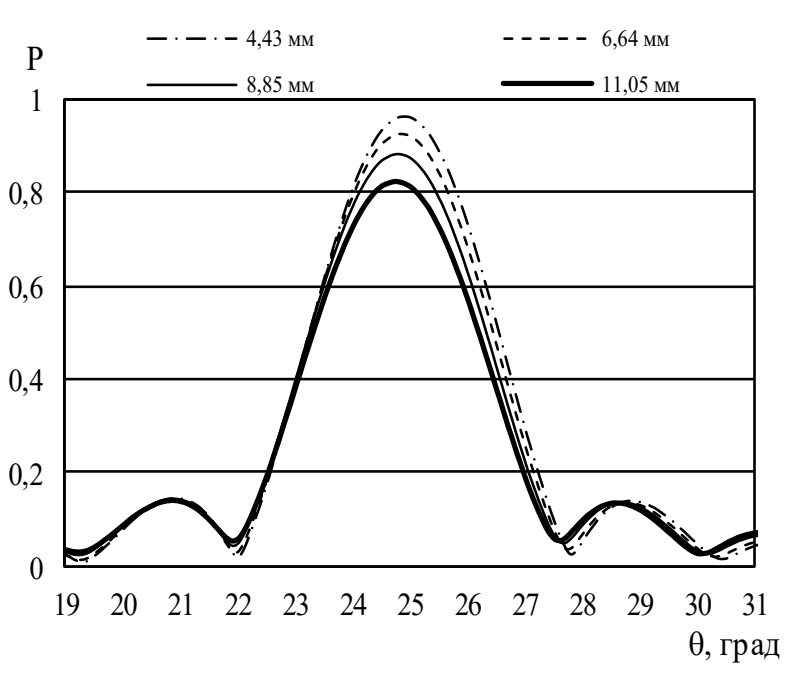

Рис. 10. Нормовані ДН АС під шестигранним обтічником при куті повороту антени $\alpha=25^{\circ}$ для різних “оптимальних” товщин стінки обтічника

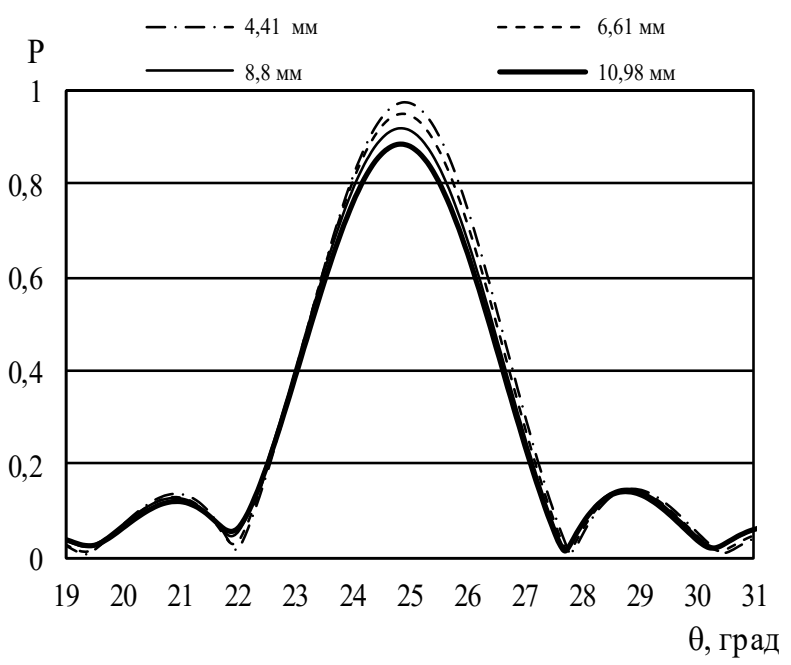

Рис. 11. Нормовані ДН АС під десятигранним обтічником при куті повороту антени $\alpha=25^{\circ}$ для різних “оптимальних” товщин стінки обтічника

Аналіз результатів, наведених на рис. 8-11, показує що розглянуті обтічники крім зменшення КПА вносять ще й кутові похибки. Так для всіх розглянутих кутів повороту антени спостерігається зміщення максимуму ДС у напрямку, протилежному повороту антени.

Оцінки зміщення максимуму ДС для різних типів обтічників та для зазначених у табл. 1 наборів оптимальних товщин їх стінок, наведені у табл. 2.

Аналіз результатів розрахунків показує, що для шестигранного обтічника напрямок максимуму ДС антени за рахунок обтічника зміщується більше, ніж для восьмигранного та десятигранного обтічників. Це дозволяє зробити висновок, що найбільш привабливою з точки зору зменшення впливу обтічника $€$ форма з кількістю граней більшою за 8.
Крім зміщення максимуму ДС, для кута повороту антени $\alpha=5^{\circ}$ спостерігається значне запливання нулів ДС та їі асиметрія.

Таблиця 2

Зміщення максимуму ДН бортової антени за рахунок обтічника при різних кутах її повороту

\begin{tabular}{|c|c|c|c|c|c|}
\hline Кут по- & $\begin{array}{c}\text { Тип } \\
\text { вороту } \\
\text { антени } \\
\text { обтічни- } \\
\alpha, \text { крад } \\
\text { ккількість } \\
\text { граней) }\end{array}$ & \multicolumn{4}{|c|}{ Кут зміщення ДН, град } \\
\cline { 2 - 6 } & 1 & 2 & 3 & 4 \\
\hline \multirow{3}{*}{5} & 6 & -0.215 & -0.31 & -0.38 & -0.51 \\
\cline { 2 - 6 } & 8 & -0.2 & -0.34 & -0.4 & -0.5 \\
\cline { 2 - 6 } & 10 & -0.2 & -0.3 & -0.415 & -0.5 \\
\hline \multirow{3}{*}{15} & 6 & -0.12 & -0.15 & -0.19 & -0.25 \\
\cline { 2 - 6 } & 8 & -0.1 & -0.17 & -0.215 & -0.265 \\
\cline { 2 - 6 } & 10 & -0.11 & -0.165 & -0.22 & -0.25 \\
\hline \multirow{3}{*}{25} & 6 & -0.09 & -0.14 & -0.2 & -0.25 \\
\cline { 2 - 6 } & 8 & -0.06 & -0.11 & -0.115 & -0.13 \\
\cline { 2 - 6 } & 10 & -0.07 & -0.11 & -0.14 & -0.15 \\
\hline
\end{tabular}

Висновки

Таким чином, у статті проведено оцінку характеристик випромінювання антенної системи під пірамідальними обтічниками в інтересах створення головок самонаведення перспективних зразків керованої ракетної зброї. Для цього був використаний розроблений в Харківському національному університеті Повітряних Сил метод розрахунку характеристик випромінювання бортових антенних систем під носовими діелектричними обтічниками, який враховує однократні перевідбиття від стінок обтічника.

Метод базується на розрахунку поля, збуджуваного випромінюючою апертурою у присутності довільної системи розсіювачів (зокрема, обтічника).

Використання обтічника може завдавати значний вплив на ДС антенної системи. Це виражається у зниженні рівня головного максимуму ДС (зниження КПА), запливанні нулів, асиметрії ДС, а також у відхиленні максимуму ДС. Отже розробка головки самонаведення повинна проводитись сумісно з обтічником, що ії закриває.

Розраховані в результаті роботи оцінки відхилення максимуму ДС антени надають розробникам головок самонаведення необхідну апріорну інформацію щодо можливих похибок вимірювання кутових координат цілей. Ці систематичні похибки повинні враховуватись при оброці сигналів ГСН.

На основі отриманих результатів обрані “оптимальні” товщини стінок обтічників для робочої частоти антени (36.6 ГГц).

Результати проведеного дослідження мають практичний інтерес при проектуванні конструкції ГСН зразків перспективної ракетної техніки. 


\section{Список літератури}

1. Карачун В.В. Гиперзвуковой прорыв: перспективы и проблемы / В.В. Карачун, В.Н. Мельник, М.Ф. Калинина // Космічна наука і технологія. - 2013. - № 2(19). - С. 63-73.

2. Разработка и тактика применения гиперзвуковых летательных аппаратов по материалам зарубежных источников / И.М. Комаров, Д.В. Зернюков, К.В. Епишин, Е.Л. Хицунов, Д.Б. Изюмов, Е.Л. Кондратюк // Инноватика и экспертиза. - 2017. - № 1(19). - С. 204-214.

3. Состояние и перспективы разработки гиперзвукового оружия / Р.В. Балмина, А.А. Губанов, М.А. Иванькин, Д.А. Лапинский // Техническая информация. - 2012. - № 1(2). - С. 1-76.

4. Woolf A.F. Conventional Prompt Global Strike and Long-Range Ballistic Missiles: Background and Issues / A.F. Woolf. - Washington, Congressional Research Service, 2018. - 50 p.

5. Каплун В.А. Обтекатели антенн СВЧ / В.А. Каплун. - М.: Сов. Радио, 1974. - 239 с.

6. Пригода Б.А. Обтекатели антенн летательных аппаратов / Б.А. Пригода, В.С. Кокунько. - М.: Машиностроение, 1978. $-120 \mathrm{c}$.

7. Raveendranath U.N. Electromagnetic Performance Analysis of a Novel Monolithic Radome for Airborne Applications / U.N. Raveendranath, M.J. Rakesh // IEEE Transactions on Antennas and Propagation. - 2009. - № 11(57). - P. $3664-3668$. https://doi.org/10.1109/TAP.2009.2026595.

8. Electrical properties analysis of conical radome / S. Liu, H. Zhou, C. Ding, L. Song // IEEE International Conference on Ubiquitous Wireless Broadband (ICUWB). - N Nanjing, China, 16-19 October 2016. $\quad$ - P. 1-4. https://doi.org/10.1109/ICUWB.2016.7790590.

9. Fast analysis of FSS radome for antenna RCS reduction // E. Martini, F. Caminita, M. Nannetti, S. Maci. // IEEE Int. Symp. On Antennas and Propagation Society. - New Mexico, USA, 9-14 July 2006. - P. 1801-1804. https://doi.10.1109/APS.2006.1710917.

10. Kim J.H. Electromagnetic analysis of a tangent-ogive dielectric radome with a metallic cap / J.H. Kim, Y.B. Park, S.C. Song // International Workshop on Antenna Technology (iWAT). - Seoul, South Korea, 4-6 March 2015. - P. 367-368. https://doi.org/10.1109/IWAT.2015.7365289.

11. Михайлов Г.Д. Эффективная площадь рассеяния зеркальной антенны с диэлектрическим обтекателем / Г.Д. Михайлов, С.Н. Кутищев, О.Е. Кирьянов // Известия вузов. - 1999. - № 9(42). - С. 879-885.

12. Modelling of effects of nose radomes on radar antenna performance / R. Lansink, J.H. Ven, T. Voigt, E. Jehamy, M. Schick, H. Schippers // 10th European Conference on Antennas and Propagation (EuCAP-2016). - Davos, Switzerland, 1015 April 2016. - P. 1-5. https://doi.org/10.1109/EuCAP.2016.7481773.

13. Prediction by simulation of electromagnetic impact of radome on typical aircraft antenna / A. Piche, G. Piau, C. Bernus, F. Campagna, D. Balitrand // The 8th European Conference on Antennas and Propagation (EuCAP 2014). - The Hague, Netherlands. - 6-11 April 2014. - P. 3205-3208. https://doi.org/10.1109/EuCAP.2014.6902510.

14. Sukharevsky O. Scattering and Radiation Characteristics of Antenna Systems under Nose Dielectric Radomes O. Sukharevsky, V. Vasylets, S. Nechitaylo // Progress In Electromagnetic Research B. - 2017. - № 76. - P. $141-157$. https://doi.org/10.2528/PIERB17032208.

15. Sukharevsky O.I. Electromagnetic wave scattering by aerial and ground radar objects / O.I. Sukharevsky. - USA, CRC Press Taylor \& Francis Group, 2015. - 288 p.

16. Nechitaylo S. Radiation characteristics of the aperture antenna with two-layer conic radome / S. Nechitaylo, O. Sukharevsky, V. Vasylets // Наука і техніка Повітряних Сил Збройних Сил України. - 2017. - № 3(28). - C. 44-47. https://doi.org/10.30748/nitps.2017.28.05.

17. Ряполов И.Е. Высокочастотный метод расчета рассеяния вторичного излучения диэлектрических частей модели беспилотного летательного аппарата / И.Е. Ряполов, В.А. Василец, О.И. Сухаревский // Системи обробки інформації. - 2014. - № 2(118). - С. 58-62.

18. Ряполов I.Є. Високочастотний асимптотичний метод розрахунку вторинного випромінювання моделі безпілотного літального апарату / І.С. Ряполов // Наука і техніка Повітряних Сил Збройних Сил України. - 2016. - № 3(24). C. 86-89.

\section{References}

1. Karachun, V.V., Melnik, V.N. and Kalinina, M.F. (2013), "Giperzvukovoy proryiv: perspektivyi i problemyi" [Hypersonic Breakthrough: Prospects and Problems], Space Science and Technology, No. 2(19), pp. 63-73.

2. Komarov, I.M., Zernyukov, D.V., Epishin, K.V., Hitsunov, E.L., Izyumov, D.B. and Kondratyuk, E.L. (2017), "Razrabotka i taktika primeneniya giperzvukovyih letatelnyih apparatov po materialam zarubezhnyih istochnikov" [Development and tactics of hypersonic aircraft based on foreign sources], Innovation and Expertise, No. 1(19), pp. 204-214.

3. Balmina, R.V., Gubanov, A.A., Ivankin, M.A. and Lapinskij, D.A. (2012), "Sostoyanie i perspektivyi razrabotki giperzvukovogo oruzhiya" [The state and prospects of developing hypersonic weapons], Technical Information, No. 1(2), pp. 1-76.

4. Woolf, A.F. (2018), Conventional Prompt Global Strike and Long-Range Ballistic Missiles: Background and Issues, Congressional Research Service, Washington, $50 \mathrm{p}$.

5. Kaplun, V.A. (1974), “Obtekateli antenn SVCh," [Radomes of microwave antennas], Sovetskoe Radio, Moscow, 239 p.

6. Prigoda, B.A. and Kokunko, V.S. (1978), "Obtekateli antenn letatelnyih apparatov" [Aircraft Radomes], Mashinostroenie, Moscow, $120 \mathrm{p}$.

7. Raveendranath, U.N. and Rakesh, M.J. (2009), Electromagnetic Performance Analysis of a Novel Monolithic Radome for Airborne Applications. IEEE Transactions on Antennas and Propagation, No. 11(57), pp. 3664-3668, https://doi.org/10.1109/TAP.2009.2026595.

8. Liu, S., Zhou, H., Ding, C. and Song, L. (2016), Electrical properties analysis of conical radome, IEEE International 
Conference on Ubiquitous Wireless Broadband (ICUWB), 16-19 October, Nanjing, China, pp. 1-4. https://doi.org/10.1109/ICUWB.2016.7790590.

9. Martini, E., Caminita, F., Nannetti, M. and Maci, S. (2006), Fast analysis of FSS radome for antenna RCS reduction, IEEE Int. Symp. On Antennas and Propagation Society, 9-14 July, New Mexico, USA, pp. 1801-1804. https://doi.org/10.1109/APS.2006.1710917.

10. Kim, J.H., Park, Y.B. and Song, S.C. (2015), Electromagnetic analysis of a tangent-ogive dielectric radome with a metallic cap, International Workshop on Antenna Technology (iWAT), 4-6 March, Seoul, South Korea, pp. 367-368. https://doi.org/10.1109/IWAT.2015.7365289.

11. Mihaylov, G.D., Kutischev, S.N. and Kiryanov, O.E. (1999), "Effektivnaya ploschad rasseyaniya zerkalnoy antennyi s dielektricheskim obtekatelem" [Radar cross section of a reflector antenna with dielectric radome], University News. Radiophysics, No. 9(42), pp. 879-885.

12. Lansink, R., Ven, J.H., Voigt, T., Jehamy, E., Schick, M. and Schippers, H. (2016), Modelling of effects of nose radomes on radar antenna performance, 10th European Conference on Antennas and Propagation (EuCAP-2016), 10-15 April, Davos, Switzerland, pp.1-5. https://doi.org/10.1109/EuCAP.2016.7481773.

13. Piche, A., Piau, G., Bernus, C., Campagna, F. and Balitrand, D. (2014), Prediction by simulation of electromagnetic impact of radome on typical aircraft antenna, The 8th European Conference on Antennas and Propagation (EuCAP 2014), 6-11 April, The Hague, Netherlands, pp. 3205-3208. https://doi.org/10.1109/EuCAP.2014.6902510.

14. Sukharevsky, O., Vasylets, V. and Nechitaylo, S. (2017), Scattering and Radiation Characteristics of Antenna Systems under Nose Dielectric Radomes, Progress In Electromagnetics Research B, No. 76, pp. 141-157. https://doi.org/10.2528/PIERB17032208.

15. Sukharevsky, O.I. (2015), Electromagnetic wave scattering by aerial and ground radar objects, CRC Press Taylor \& Francis Group, USA, 288 p.

16. Nechitaylo, S.V., Sukharevsky, O.I. and Vasilets, V.O. (2017), Radiation characteristics of the aperture antenna with two-layer conic radome, Science and Technology of the Air Force of Ukraine, No. 3(28), pp. 44-47. https://doi.org/10.30748/nitps.2017.28.05.

17. Ryapolov, I.E., Vasylets, V.A. and Sukharevsky, O.I. (2014), "Vyisokochastotnyiy metod rascheta rasseyaniya vtorichnogo izlucheniya dielektricheskih chastey modeli bespilotnogo letatelnogo apparata" [High-frequency method for calculating the scattering of secondary radiation from the dielectric parts of the unmanned aerial vehicle model], Information Processing Systems, No. 2(118), pp. 58-62.

18. Ryapolov, I.E. (2016), "Vysokochastotnyi asymptotychnyi metod rozrakhunku vtorynnoho vyprominiuvannia modeli bezpilotnoho litalnoho aparatu" [High-frequency asymptotic method of calculation of the secondary radiation model unmanned aerial vehicle], Science and Technology of the Air Force of Ukraine, No. 3(24), pp. 86-89.

Надійшла до редколегії 26.12.2019

Схвалена до друку 11.02.2020

\section{Відомості про авторів:}

\section{Нечитайло Сергій Вячеславович}

доктор технічних наук

старший науковий співробітник

начальник науково-дослідної лабораторії

Харківського національного університету

Повітряних Сил ім. І. Кожедуба,

Харків, Україна

https://orcid.org/0000-0002-5341-8684

\section{Ряполов Іван Свгенович}

кандидат технічних наук старший науковий співробітник

Харківського національного університету

Повітряних Сил ім. І. Кожедуба,

Харків, Україна

https://orcid.org/0000-0002-3139-1644

\section{Білий Денис Вікторович}

курсант

Харківського національного університету

Повітряних Сил ім. І. Кожедуба,

Харків, Україна

https://orcid.org/0000-0002-7852-546X

\section{Ярчуківський Данііл Ігорович}

курсант

Харківського національного університету

Повітряних Сил ім. І. Кожедуба,

Харків, Україна

https://orcid.org/0000-0001-8856-7367

\section{Information about the authors:}

\author{
Nechitaylo Sergey \\ Doctor of Technical Sciences \\ Senior Research \\ Chief of Scientific Research Laboratory \\ of Ivan Kozhedub Kharkiv \\ National Air Force University, \\ Kharkiv, Ukraine \\ https://orcid.org/0000-0002-5341-8684
}

\section{Ivan Ryapolov}

Candidate of Technical Sciences

Senior Research Associate

of Ivan Kozhedub Kharkiv

National Air Force University,

Kharkiv, Ukraine

https://orcid.org/0000-0002-3139-1644

\section{Denis Biliy}

Cadet

of Ivan Kozhedub Kharkiv

National Air Force University,

Kharkiv, Ukraine

https://orcid.org/0000-0002-7852-546X

\section{Daniil Yarchukivskiy}

Cadet

of Ivan Kozhedub Kharkiv

National Air Force University,

Kharkiv, Ukraine

https://orcid.org/0000-0001-8856-7367 


\title{
ВЛИЯНИЕ НОСОВЫХ ОБТЕКАТЕЛЕЙ ПИРАМИДАЛЬНОЙ ФОРМЫ НА ХАРАКТЕРИСТИКИ ИЗЛУЧЕНИЯ БОРТОВЫХ АНТЕННЫХ СИСТЕМ
}

\author{
С.В. Нечитайло, И.Е. Ряполов, Д.В. Билый, Д.И. Ярчукивский
}

Современное ракетное вооружение зачастую оснащается радиолокационными головками самонаведения (ГСН). Носовые диэлектрические обтекатели, закрывающие антенные системы радиолокаиионных головок самонаведения современного ракетного вооружения, оказывают существенное влияние на их основные радиотехнические характеристики. Указанное влияние выражается в снижении уровня главного максимума диаграммы направленности (снижении коэффициента усиления антенны), запльвании нулей диаграммы направленности и отклонении ее максимума. В связи с этим актуальным становится вопрос оченки негативного влияния обтекателя на основные радиотехнические характеристики ГСН с иелью его учета при проектировании ГСН и при разработке боевых алгоритмов наведения управляемого ракетного оружия. Одними из наиболее технологичных в производстве являются обтекатели пирамидальной формы, которые могут рассматриваться как перспективные для гиперзвукового ракетного вооружения. В статье представлены результаты расчета характеристик излучения апертурных антенн, укрытых носовыми диэлектрическими обтекателями указанного типа. Для решения описанной задачи использован разработанный ранее в Харьковском национальном университете Воздушных Сил метод расчета поля излучающей апертурь в присутствии произвольной системы рассеивателей (в частности обтекателя). Метод может использоваться и для обтекателей других типов и форм. Рассмотрены три типа пирамидальных носовых обтекателей, отличающиеся количеством граней. Основываясь на полученных результатах расчетов даны рекомендачии по выбору оптимальных толщин стенок обтекателей. Оченены ошибки определения угловых координат иелей, вносимые рассмотренными обтекателями при разных углах сканирования ГСН.

Ключевые слова: апертурная антенна, носовой обтекатель, характеристики излучения, головка самонаведения.

\section{INFLUENCE OF THE NOSE SHOWERS OF THE PYRAMIDAL FORM ON THE CHARACTERISTICS OF RADIATION OF ON-BOARD ANTENNA SYSTEMS}

S. Nechitaylo, I. Ryapolov, D. Biliy, D. Yarchukivskiy

Modern guided missiles are often equipped with homing heads which operates in the radar band. They are located under the dielectric nose radomes which have a significant impact on the main radiation charakteristiks of the homing head. This leads to a decrease in the level of the main maximum of the radiation pattern (decrease in antenna gain), the blur of zeros of the radiation pattern and the deviation of its maximum. In this regard, the problem of astimation the negative impact of the radome on the main radiation characteristics of the homing heads becomes relevant. It must be taking into account when designing the homing heads and in the development of combat algorithms for guided missile weapons. One of the simplest in production are pyramidal radomes. They can be considered promising for hypersonic missile weapons. The article presents the results of calculating the radiation characteristics of aperture antennas covered with nose dielectric radomes of the described type. To solve this problem, we use a method for calculating the radiation characteristics of homing head antennas placed inside the nose dielectric radomes. This method was developed previously at Kharkiv National Air Force University. It's based on the calculation method for field generated by radiation aperture given that an arbitrary system of scatterers (particularly, radome) exists in its vicinity. The method can be used for other types and shapes of radomes. It can also be used to evaluate the scattering characteristics of homing heads under radomes. The article discusses three types of nose radomes with pyramid form. They differ from each other in the number of edges. On the basis of the obtained calculation results, recommendations on the choice of the optimal radomes wall thicknesses were given. The angle errors made by the radomes for different scanning angles of the homing head antenna are estimated.

Keywords: aperture antenna, nose radome, radiation characteristics, homing head. 